Thank you, one and all, for helping to make the OPFA a strong and enduring entity.

Lorne F. Riley, R.P.F.

Chairman, Recognition and Awards Committee

\section{Peter Marshall, RPF, named as vice-president of the ABCPF}

Dr. Peter Marshall, R.P.F., Professor and Associate Dean, officially took office as vice-president of the Association of B.C. Professional Foresters (ABCPF) on February 28, 2002. Peter's inauguration occurred at the annual general meeting and conference of the ABCPF in Nanaimo, B.C. His new position marks the beginning of his fourth year in the Association's council, prior to which, he was an active member of the ABCPF board of examiners for almost a decade. Peter will become the 55th president of the ABCPF at the annual general meeting in Penticton next February.

In the coming year, Peter will be serving a dual function on the ABCPF Council. He will assume the role of director of discipline and enforcement, as well as his new vice-president capacity. In his director role, he will lead efforts to implement changes to the Association's complaint review and discipline processes. Late last year, a task force reviewed the Association's existing discipline process and made recommendations for its improvement. These changes will be implemented over the coming year and are aimed at incorporating negotiation, mediation, and arbitration into the discipline process to create a broad range of ways to deal with complaints lodged against members, aside from formal investigations and hearings. The changes are designed to ensure the discipline process continues to serve the public and the Association membership well.

\title{
Model Forest News
}

\section{Renewal of Canada's Model Forest Program}

The Government of Canada has announced its renewed commitment to the Model Forest Program for another fiveyear period (Phase III), extending from April 1, 2002 to March 31, 2007. The Phase II evaluation recognized the Program's relevance and effectiveness in meeting its goals.

The Bas-Saint-Laurent Model Forest Phase II evaluation showed us to have attained our individual objectives, making us eligible for participation in Phase III of the Program. To prepare our proposal for the third phase, we held consultations with our various partners and on-the-ground stakeholders and collaborators, followed by discussion sessions to define our priorities for the next five years.

Building on the outcome of these exercises, we put together a five-year action plan in keeping with the Program objectives, the Model Forest's mission and the priorities defined during the consultation process. Planned activities are grouped under five objectives.

\section{Promote the development and adoption of forest management models}

The Bas-Saint-Laurent Model Forest will continue to develop, improve and promote the two management models being tested, adapt them, and also develop other models that are more suited to Québec's public forest conditions. As well, we will continue to influence practices locally, but also, and especially, regionally, provincially and even nationally.

\section{Help improve sustainable forest management systems}

We wish to improve our sustainable forest management systems by integrating new knowledge and new sustainability concepts. Among other things, the systems will incorporate performance indicators so as to identify and document the best approaches and tools available in order to promote them beyond the Model Forest's boundaries.

\section{Foster the development and application of new forest management techniques}

We wish to continue developing and implementing new management techniques that protect and enhance all resources in the forest. We intend to continue our efforts in this regard in order to improve current practices as well as develop new tools on the cutting edge of knowledge. Moreover, we intend to encourage application of these new techniques wherever conditions allow.

\section{Communicate and disseminate results}

Communications and outreach will continue to be priorities for the BasSaint-Laurent Model Forest in Phase III of the Program. We will be counting on the multiplying effect of our accomplishments to reach as many stakeholders as possible and thereby expand our sphere of influence.

\section{Participate in Network activities}

The Canadian Model Forest Network provides its members with a unique opportunity to share the knowledge we have gained and work together to achieve common objectives. The Bas-Saint-Laurent Model Forest intends to work collaboratively with the other model forests to strengthen the Network and increase awareness of our past and future initiatives.
Louisiana-Pacific Canada Ltd.

\author{
A CIF/IFC Corporate Sustaining Member
}

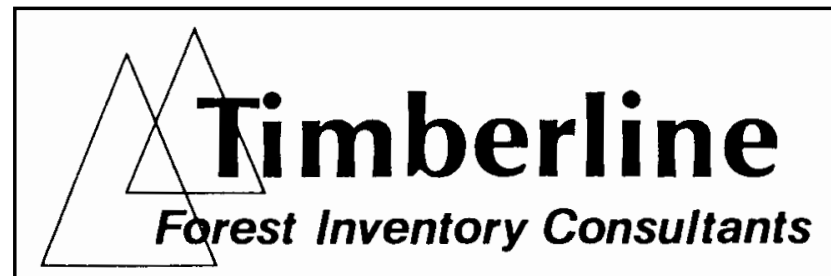

A CIF/IFC Corporate Sustaining Member 